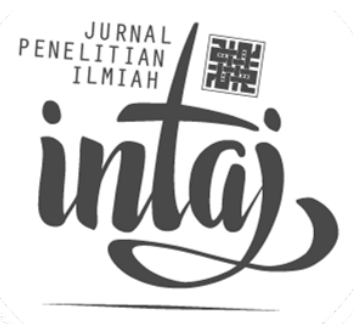

\title{
A JAVANESE PANJ ROMANCE: ANALISIS STRUKTUR CERITA PANJI PADA NASKAH WANGBANG WIDEYYA
}

Fitrotul Hikmah (fitrotulhikmah719@gmail.com)1, Roihanah (roihanah@alqolam.ac.id)1

${ }^{1)}$ IAI Al-Qolam Gondanglegi Malang

(Received: June 2017 / Revised: September 2017 / Accepted: September 2017)

\begin{abstract}
Panji's story is a classic romance originating from East Java. One variant of Panji's story is Wangbang Widèya: A Javanese Panji Romance. Research on this manuscript is rarely done, or there is research on the same topic, but different theoretical basis as a tool for study. The purpose of this study is to indirectly examine the literary aspect that possible further research coupled with intrinsic research. Research focuses on studying intrinsic aspects that include: theme, plot, character and characterization, and background story.
\end{abstract}

This research is library study using qualitative research method. The source of this research data is Wangbang Widèya: A Javanese Panji Romance. This process begins with data collection in the form of primary and secondary data. The analysis comprises data reduction, data classification, and data display. In the final process of data display, it has presented data ready to be analyzed.

The results show: (1) the theme of romance is an absolute theme in Wangbang Widèya: A Javanese Panji Romance; (2) the groove is loose because it is easily inserted with other stories that complement the story as a whole; (3) the characters and the characterizations are static, namely if the character is good then he will get the victory, but if the character is evil it will get defeated; (3) the 
settings in Wangbang Widèya: A Javanese Panji Romance cover the setting of place, time, atmosphere, and social aspect as the explanation of the character strata.

Keywords: the structure of the story, manuscript, Wangbang Widèya: A Javanese Panji Romance

\section{PENDAHULUAN}

Cerita Panji merupakan folklore lokal yang dibungkus oleh latar belakang sejarah kerajaan-kerajaan di Jawa Timur. Kerajaan yang menjadi pokok cerita adalah kerajaan Kediri (Daha) dengan Kerajaan Jenggala. Banyak sekali versi Cerita Panji yang beredar dalam bentuk cerita utuh maupun penyerta suatu pertunjukan dengan berbagai versi bahasa.

Sulit diketahui oleh masyarakat umum tentang Cerita Panji yang betul-betul asli. Hal ini karena penyebaran Cerita Panji bukan hanya di Jawa dan Bali, tetapi terdapat juga di Sumatera dan Jazirah Melayu, Borneo, Selebes, dan Lombok. Tak terkecuali Kamboja, Thailand, dan Birma ${ }^{1}$. Namun, semua cerita Panji yang ada mempunyai motif dan pola yang hampir sama berupa pertemuan-pengembaraan-pertemuan.

Penelitian atau kajian terhadap Cerita Panji tidak hanya dilakukan oleh penelitipeneliti Indonesia akan tetapi juga dilakukan oleh peneliti asing, salah satunya adalah C.C. Berg. Berg berpendapat bahwa penyebaran cerita Panji ialah: Pamalayu $(1227 M)$, sebagai permulaan dan \pm 1400 sebagai tahun akhir. Pendapat ini dikemukakan pada tahun 1922. ${ }^{2}$ Selain Berg, Stuart membicarakannya dari segi kesusastraannya, Roorda dari kisahnya yang mandiri, Poerbatjaraka dari varianvarian cerita Panji, dan yang terakhir diketahui dilakukan oleh Kieven-peneliti dari Goethe Universitat Franfurt, Jerman. ${ }^{3}$ Peneliti lokal yang menelaah cerita Panji juga berlimpah, salah satunya Eggy Fadjar Andalas (2016) meneliti cerita Panji dengan judul "Sastra Lisan Lakon Lahire Panji Pada Pertunjukan Wayang Topeng Malang Padepokan Mangun Dharma". Koes Yuliadi (2013) dengan tulisan "From Arca to Arja: "Panji” Adaptation at Arja Performance in Bali” yang meneliti cerita Panji berkaitan dengan Tari Arja di Bali.

Salah satu varian dari Cerita Panji yang beredar pada masyarakat Bali adalah Wangbang Wideya. Judul Wangbang Wideya dalam buku Wangbang Wideya: A Javanese Panji Romance diambil dari pelaku utama yakni Wangbang Wideya Apañji Wireswara. Alih aksara sekaligus penelaahan lebih intens pada Cerita Panji

\footnotetext{
${ }^{1}$ O. Robson. Wangbang Wideya: A Javanese Panji Romance. (The Hague: Martinus Nijhoff, 1971), hlm. 15.

${ }^{2}$ R. Ng. Poerbatjaraka. Cerita Panji Dalam Perbandingan. (Jakarta: Gunung Agung, 1968), hlm. 403.

${ }^{3}$ Ida Bagus Manuaba, Adi Setijowati, dan Puji Karyanto. Keberadaan dan Bentuk Transformasi Cerita Panji, Litera, 1 Volume 12, 2013
} 
dalam Wangbang Wideya dilakukan oleh S.O. Robson (1971). Wangbang Wideya sebagai salah satu varian cerita Panji nyaris tidak tersentuh oleh peneliti Indonesia. Tulisan yang pernah mengupas Wangbang Wideya dilakukan oleh Eva Cahyaning Tyas (2014) meneliti Wangbang Wideya dengan tinjauan teori Vladimir Proop, "Aspek Folklorik Carita Panji sajrone Kidung Wangbang Wideya (Tintingan Struktur Naratif)". W Wulandari (1999) meneliti Wangbang Wideya dengan pendekatan budaya yang berjudul "Kajian Unsur Budaya Dalam Kidung Wangbang Wideya". Berangkat dari inilah, peluang untuk meneliti yang dilakukan oleh peneliti-peneliti lain dari berbagai disiplin keilmuan masih terbuka lebar.

Kajian tentang Wangbang Wideya: A Javanese Panji Romance dirumuskan sebagai analisis dalam struktur cerita. Hal ini diasumsikan bahwa analisis struktur cerita secara interrnal pada Wangbang Wideya: A Javanese Panji Romance belum ada yang melakukan berdasarkan paparan-paparan di atas. Sejalan dengan rumusan masalah pada kalimat sebelumnya, dapat diuraikan tujuan dari penelitian ini untuk mengetahui aspek-aspek intrinsik yang ada dalam cerita Wangbang Wideya.

Manfaat dalam penelitian ini, diharapkan, secara teoritis untuk pengayaan pengkajian secara intrinsik terutama pada naskah-naskah kuno, salah satunya lewat Wangbang Wideya. Secara praktis, penelitian ini diharapkan dapat mendorong peneliti-peneliti lain untuk menggali dan mendalami naskah-naskah kuno dengan melakukan penelitian dari berbagai disiplin ilmu. Selain itu, eksplorasi naskahnaskah kuno akan memperkaya kajian kebudayaan nenek moyang Indonesia dari zaman lampau.

Teori yang digunakan dalam kajian Wangbang Wideya adalah kajian intrinsik pada cerita yang ada di dalamnya. Kajian intrinsik pada sastra berpusat pada aspek tema, tokoh dan penokohan, alur, serta latar. Tema adalah gagasan, ide atau pikiran utama dalam karya sastra baik secara eksplisit maupun implisit. ${ }^{4}$ Tema dapat dikenali lewat dialog, deskripsi cerita, maupun ucapan tokoh. Alur adalah jalinan peristiwa pada suatu lakon untuk mencapai efek tertentu. ${ }^{5}$ Suatu cerita dalam karya sastra lama atau baru dapat dipastikan mempunyai urut-urutan cerita yang membentuk hubungan kausalitas. Hubungan kausalitas itu bertujuan untuk penertiban suatu cerita, supaya bisa difahami oleh pembaca atau penonton tentang maksud atau isi yang ada di dalamnya. Ambil contoh misalnya, Romeo bunuh diri karena mengira bahwa Juliet sudah mati. Kata 'karena' merupakan kata sambung untuk menghubungkan kedua peristiwa itu dengan menjelaskan bahwa yang pertama disebabkan oleh peristiwa kedua. Lain dengan cerita. karena cerita memerlukan kata dan atau lalu atau kemudian untuk menghubungkan dua peristiwa. Jadi dalam kisah tersebut, Romeo bunuh diri dan kemudian Juliet melakukan hal yang sama, dengan

\footnotetext{
${ }^{4}$ Panuti Sudjiman, Kamus Istilah Sastra, (Jakarta: Universitas Indonesia Press, 1998), hlm. 78.

${ }^{5}$ Ibid, 4.
} 
kata lain, plot menunjukkan peristiwa-peristiwa secara kausatif. Sedangkan cerita secara kronologis hanya menceritakan secara berurutan. oleh karena itu, kata 'mengapa' adalah kata ganti penanya yang paling cocok untuk mengamati paradigma plot dalam drama maupun novel. ${ }^{6}$

Tokoh merupakan pelaku sentral yang menggerakkan cerita mulai dari eksposisi sampai denoument. dari segi keterlibatan dalam keseluruhan cerita, tokoh fiksi dibedakan menjadi dua yakni tokoh sentral atau tokoh utama dan tokoh periferal atau tokoh tambahan (bawahan). Berdasarkan watak atau karakter, yakni segi-segi yang mengacu pada perbauran antara minat, keinginan, emosi, dan moral yang membentuk tokoh, meliputi tokoh sederhana, simple characters atau flat characters dan tokoh kompleks, complex characters, atau round characters. Tokoh utama dapat ditentukan dengan tiga cara. Pertama, tokoh itu paling terlibat dengan makna atau tema. Kedua, tokoh itu yang paling banyak berhubungan dengan tokoh lain. Ketiga, tokoh itu yang paling banyak memerlukan penceritaan. ${ }^{7}$

Penokohan adalah proses penampilan tokoh dengan pemberian watak, sikap, atau kebiasaan tokoh pemeran suatu cerita. ${ }^{8}$ Menurut Panuti Sudjiman, penyajian watak tokoh dan penciptaan citra tokoh ini disebut dengan penokohan. ${ }^{9}$ Penokohan menunjuk pada penempatan tokoh-tokoh tertentu dengan watak-watak tertentu dalam sebuah cerita. ${ }^{10}$ Berbagai statement di atas dapat disimpulkan bahwa penyajian sifat, watak, dan kebiasaan akan menjadi tampilan ciri khas tokoh. Hal ini merujuk pada tokoh dengan pelekatan sifat ataupun watak yang dipaparkan oleh pengarang.

Latar secara umum mengacu pada ruang terjadinya suatu cerita. Latar adalah segala keterangan mengenai waktu, ruang, dan suasana terjadinya lakuan dalam karya sastra. ${ }^{11}$ Secara garis besar, deskripsi latar fiksi dapat dikategorikan dalam tiga bagian, yakni latar tempat, latar waktu, latar suasana, dan latar sosial. Latar tempat menyangkut deskripsi tempat suatu peristiwa terjadi, misalnya latar tempat dalam kubah, yang menunjukkan latar pedesaan, perkotaan atau latar tempat dalam lainnya. Latar waktu mengacu pada saat terjadinya peristiwa dalam plot, seperti waktu pagi, sore atau petang, dan waktu malam. Latar suasana merujuk pada penggambaran keadaan lingkungan. Pendeskripsian lingkungan dalam berbagai rangkaian kalimat serta paparan gejala-gejala alam, akan dapat dirumuskan oleh pembaca

\footnotetext{
${ }^{6}$ Bakdi Soemanto, Jagat Teater, (Yogyakarta: Media Pressindo, 2001), hlm. 16.

${ }^{7}$ Suminto A. Sayuti, Berkenalan dengan Prosa Fiksi, (Yogyakarta: Gama Media, 2000), hlm. 74-78.

${ }^{8}$ Abdul Razak Zaidan, Anita K. Mustapa, dan Haniah, Kamus Istilah Sastra. (Jakarta: Balai Pustaka, 1994), hlm. 206

${ }^{9}$ Sudjiman, Kamus Istilah..., hlm. 58.

${ }^{10}$ Burhan Nurgiyantoro, Teori Pengkajian Prosa Fiksi, (Yogyakarta: Gadjah Mada University, 1995), hlm. 165.

${ }^{11}$ Sudjiman, Kamus Istilah..., hlm. 48.
} 
bahwa suasana yang melingkupi sebagian cerita bersifat kesedihan, kekhawatiran, kesenangan, maupun kecemasan.

Secara historis, latar sosial merupakan lukisan status sosial yang menunjukkan hakikat seorang atau beberapa orang tokoh dalam masyarakat yang ada di sekelilingnya atau berhubungan dengan strata sosial. ${ }^{12}$

\section{METODE PENELITIAN}

Metode yang digunakan dalam penelitian ini adalah metode penelitian kualitatif dengan analisis tekstual. Hal ini bertujuan untuk mengungkapkan aspek-aspek yang menjadi obyek permasalahan dalam penelitian ini berkaitan dengan proses penganalisaan dari aspek cerita (intrinsik).

Dalam penelitian kualitatif tidak digunakan istilah populasi, tetapi oleh Spradley dinamakan "social situation" atau situasi sosial yang terdiri atas tiga elemen yaitu: tempat (place), pelaku (actor), dan aktifitas (activity) yang berinteraksi secara sinergis ${ }^{13}$. Aktifitas dalam penelitian berupa proses pengambilan data hingga penafsirannya merupakan salah satu bagian obyek penelitian. Sumber data adalah buku Wangbang Wideya: A Javanese Panji Romance karya S.O Robson (1971) yang di dalamnya memuat kidung Wangbang Wideya. Selain itu, penggalian data secara kepustakaan juga diperlukan untuk menelaaah cerita-cerita Panji dan berbagai penelitian yang ada di dalamnya dan dilakukan oleh peneliti lain. Teknik pengumpulan data dengan cara triangulasi yakni penggabungan antara teknik dokumentasi, observasi dan teknik yang lain. Teknik ini terbukti cukup siginifikan dalam telaah Wangbang Wideya dari segi intrinsik cerita, karena pada saat pengambilan data, proses observasi dan dokumentasi merupakan salah satu langkah yang bersamaan dengan teknik kredibilitas atau kevalidan data.

Langkah berikutnya adalah proses analisis data dengan cara mereduksi data. Data yang telah dikumpulkan melalui studi pustaka dalam bentuk dokumentasi dan observasi akan direduksi berdasarkan topik masalah pada penelitian ini. Data-data yang dipilih adalah data yang bertopik cerita Panji dalam berbagai penelitian maupun sejenisnya seperti cerita Wangbang Wideya.

Cerita Wangbang Wideya (dalam versi Bahasa Inggris) ditransliterasi ke Bahasa Indonesia supaya analisis dari aspek intrinsik mudah dilakukan. Penyajian data sebagai bagian dari metode penelitian kualitatif berusaha memaparkan hasil

\footnotetext{
12 Sayuti, Berkenalan dengan..., hlm. 126-127.

${ }^{13}$ Sugiyono. Metode Penelitian Kuantitatif, Kualitatif, dan R\&D, (Bandung : Alfabeta, 2016), hlm. 215
} 
investigasi dari proses reduksi data. Hal ini didapatkan bahwa penelitian intrinsik pada naskah Wangbang Wideya selama ini belum ada yang melakukan. Walaupun ada penelitian sejenis, landasan teori untuk analisisnya sangat berbeda. Selain itu, pendekatan intrinsik dalam naskah Wangbang Wideya merupakan salah satu langkah sederhana dalam proses analisis sastra. Proses verification data merupakan tahap akhir pada prosedur penelitian Wangbang Wideya. Pada akhirnya, naskah Wangbang Wideya dapat ditelaah dari segi intrinsik ceritanya.

\section{HASIL DAN PEMBAHASAN}

\subsection{Tema Cerita Wangbang Wideya dalam Buku Wangbang Widèya: A Javanese Panji Romance}

Tema Panji dalam Wangbang Wideya di buku Wangbang Widèya adalah tentang asmara. Di dalamnya menceritakan tentang para lelaki yang memperebutkan seorang perempuan, rasa frustasi, dan terkabulnya suatu keinginan. Kakawin atau kidung tersebut juga menceritakan kemarahan seorang laki-laki, patah hati, keputusasaan, hawa nafsu yang begitu memuncak, dan akhirnya kesuksesan dari kerja kerasnya. ${ }^{14}$ Namun, tema asmara merupakan tema sentral yang bisa mengakibatkan adanya peperangan. Permasalahan ini bermula dari tunangan Raden Makaradwaja yang menikah dengan penemunya, yakni putra mahkota dari kerajaan Kembang Kuning. Dikisahkan bahwa Raden Warastrasari tidak mencintai putra mahkota Kembang Kuning. Namun dengan penuh kerelaan, Raden Singhamatra mau menunggu Putri Daha hingga mencintainya.

Kabar yang berbeda telah sampai di telinga putra mahkota Kuripan, tentang pernikahan Raden Warastrasari dengan Raden Singhamatra. Kabar yang demikian membuat Raden Makaradwaja marah. Namun di satu sisi, Raden Warastrasari merasa jatuh cinta terhadap Raden Makaradwaja yang menyamar dengan nama Panji. Di sisi lain, ada orang laki-laki yang patah hati, yakni Raden Singhamatra walaupun telah berstatus suami dari Puteri Daha, namun dia tidak bisa menyen-tuhnya. Dia merasa hatinya hancur, karena melihat Dewi Warastrasari senang dengan pertunjukan yang digelar Panji.

Raden Singhamatra begitu putus asa melihat Raden Warastrasari yang tidak dapat dijangkau. Sementara itu, walaupun Raden Warastrasari sedang melihat pertunjukan raket yang digelar oleh Raden Makaradwaja, Raden Makaradwaja yang merasa tidak bisa lagi membendung keinginannya terhadap Raden Warastrasari, tidak mungkin menculik Raden Warastrasari, karena perbuatan itu sungguh terhina. Dahulu, Raden Makaradwaja menduga bahwa tidak ada perempuan lain yang bisa

${ }^{14}$ S.O. Robson, Wangbang Wideya..., hlm. 28. 
menandingi kecantikan Raden Kesawati. Akan tetapi kecantikan Raden Kesawati ada yang menandingi sekarang, yakni Raden Warastrasari. Raden Makaradwaja lebih baik mati dari pada tidak mendapatkan Raden Warastrasari.

Raden Makaradwaja begitu sedih dengan keberadaan Raden Warastrasari yang sudah menikah dengan pangeran lain. Dikarenakan kesedihan yang memuncak, Raden Makaradwaja ingin menculik Raden Warastrasari akan tetapi keinginan itu dicegah oleh orang-orang dekatnya.

Tema dalam Wangbang Widèya di buku Wangbang Widèya: A Javanese Panji Romance tidak berbeda dengan tema cerita Panji secara umum, yakni proses pengembaraan seorang pangeran untuk menemukan tunangannya. Hal ini dilakukan oleh Raden Makaradwaja untuk menemukan kembali Raden Warastrasari setelah mengalami berbagai rintangan dan hambatan.

\subsection{Alur Cerita Wangbang Widèya dalam buku Wangbang Widèya: A Javanese Panji Romance}

Suatu cerita dalam karya sastra lama atau baru dapat dipastikan mempunyai uruturutan cerita yang membentuk hubungan kausalitas. Hubungan kausalitas itu bertujuan untuk penertiban suatu cerita supaya bisa difahami oleh pembaca atau penonton tentang maksud atau isi yang ada di dalamnya. Ambil contoh misalnya, Romeo bunuh diri karena mengira bahwa Juliet sudah mati. Kata 'karena' merupakan kata sambung untuk menghubungkan kedua peristiwa itu, dengan menjelaskan bahwa yang pertama disebabkan oleh peristiwa kedua. Hal ini berbeda dengan cerita. Cerita memerlukan kata 'dan', 'lalu', atau 'kemudian' untuk menghubungkan dua peristiwa. Dalam kisah Romeo dan Juliet, misalnya, Romeo bunuh diri dan kemudian Juliet melakukan hal yang sama. Dengan kata lain, plot menunjukkan peristiwa-peristiwa secara kausatif, sedangkan cerita secara kronologis. oleh karena itu, kata 'mengapa' adalah kata ganti penanya yang paling cocok untuk mengamati paradigma plot dalam drama maupun novel. ${ }^{15}$

Eksposisi adalah pemaparan dan pengenalan awal cerita. Kidung Wangbang Wideya dalam Wangbang Wideya: A Javanese Panji Romance secara inti terbagi dalam tiga bab. Bab pertama yakni Raja Kuripan mempunyai seorang putra yang sangat tampan, pemberani, bijaksana, suka menolong orang lain, dan pintar membaca kitab suci. Laki-laki itu bernama Raden Makaradwaja. Putri Daha sebagai tunangannya telah menghilang, sehingga Raden Makaradwaja mencari ke mana-mana. Namun kecantikan Raden Dyah Kesawati telah membuatnya beralih tujuan. Kabar tentang Raden Makaradwaja menikah lagi, terdengar sampai ke Daha, sehingga kesedihan

${ }^{15}$ Bakdi Soemanto, Jagat Teater..., hIm. 16. 
Raja dan Ratu Daha semakin bertambah. Raden Warastrasari sewaktu menghilang berjarak kurang tiga bulan dari pernikahannya.

Sementara itu, Putri Daha berada di hutan Kembang Kuning selama delapan hari, hingga ia ditemukan oleh Raden Singhamarta. Dari sinilah mulai terlihat perjalanan plot berproses menuju keteraturan. Bab pertama sebagai pembuka cerita dalam Wangbang Wideya di buku Wangbang Widèya: A Javanese Panji Romance telah diawali penjelajahan Raden Makaradwaja disebabkan Puteri Daha menghilang. Namun, perjalanan itu terhalang dikarenakan Raden Makaradwaja terpikat wanita lain, yakni Raden Dyah Kesawati.

Urut-urutan cerita yang benar harus berjalan menuju satu arah, lalu mulai longgar ketika disisipi dengan adanya eksposisi lain, yakni keadaan Puteri Daha (Raden Warastrasari) ketika berada di hutan Kembang Kuning. Puteri Daha ditemukan oleh Raden Singhamatra karena dia hendak berburu. Namun cerita berbalik lain, ketika Raden Warastrasari dibawa pulang dan diantar oleh Raden Singhamatra. Akhirnya Raden Singhamatra menikah dengan Raden Warastrasari disebabkan dia berhasil menemukan Puteri Daha. Eksposisi ini mulai bertautan dengan eksposisi awal, ketika Raden Makaradwaja memulai petualangannya di Daha. Raden Makaradwaja berada di Daha disebabkan Raden Warastrasari menikah dengan Raden Singhamatra.

Eksposisi awal dalam Wangbang Widèya di buku Wangbang Widèya: A Javanese Panji Romance, terlihat bahwa alur adalah alur longgar, karena mudah sekali ada penyisipan-penyisipan cerita lain. Walaupun terjadi penyisipan-penyisipan cerita lain, namun kesemuanya berproses menuju satu kesatuan cerita yakni tentang perjalanan Raden Makaradwaja ketika berusaha merebut tunangannya, Raden Warastrasari. Dalam eksposisi bab pertama, terjabarkan dengan jelas tentang situasi kerajaan Kuripan, kerajaan Kembang Kuning, dan kerajaan Daha. Eksposisi dalam bab awal juga mengetengahkan orang-orang yang terlibat di dalam kerajaan Daha, seperti Raden Makaradwaja beserta pembantunya. Kerajaan Kembang Kuning dengan tokoh Raden Singhamatra. Kerajaan Daha diwakili tokoh raja, ratu, Puteri Daha beserta para punggawa.

Eksposisi dalam bab kedua memaparkan keberadaan Raja Lasem yang berkehendak merebut Puteri Daha. Raja Lasem adalah seseorang yang terkenal dengan keberanian, kekuatan, dan kemahiran dalam berperang. Dia juga seorang raja yang bergelimang dengan harta dan tentara yang dia miliki begitu banyak. Raja Lasem mempunyai sifat jahat karena dia terkenal sebagai musuh yang sangat kejam. Di samping itu, dia mempunyai beberapa selir, seorang yang sukses dalam bercinta, serta raja yang suka dengan para wanita. Raja Lasem ingin menyerang Daha karena dia tidak bisa membawa Raden Warastrasari. Setelah Raja Lasem mendengar kabar tentang 
pernikahan puteri Daha maka dia menegaskan untuk berperang dengan Kerajaan Daha.

Dalam perjalanan menuju Daha, mereka menyerang dan meluluhlantakkan semua desa, serta penduduknya mereka tangkap. Jika mereka melawan akan dianggap sebagai musuh oleh pasukan Raja Lasem, tanpa terkecuali apakah itu laki-laki atau perempuan. Mereka menangkap anak-anak dan perempuan. Para tumenggung dan demang menyerahkan beberapa wanita cantik. Beberapa dari wanita cantik itu mereka jadikan selir, dan semua wanita mereka perkosa. Para penduduk tidak sanggup melawan, karena mereka sangat kuat. Mereka melarikan diri ke sekitar bukit-bukit Daha jika tidak berani melawan atau mencoba bertahan. Setiap peternakan mereka bantai, dan Raja Lasem beserta pasukannya bersuka ria atas kekalahan penduduk.

Pendeskripsian yang begitu jelas dalam bab dua diikutkan dalam salah satu aspek eksposisi dalam Wangbang Widèya: A Javanese Panji Romance. Raja Lasem menyerang Daha dengan motif ingin merebut Puteri Daha. Walaupun terletak tidak di awal cerita, namun deskripsi tentang sepak terjang Raja Lasem beserta pasukan-nya dianggap mewakili eksposisi karena memberikan informasi baru yang dapat melengkapi dalam Wangbang Widèya: A Javanese Panji Romance. Hal ini bisa diketahui lewat tempat, nama, serta motif yang melatarbelakangi mereka bertindak seperti itu. Dikarenakan Raja Lasem ingin menyerang Daha, maka Raden Makaradwaja beserta Raden Singhamatra bersiap mempertahankan kerajaan Daha.

Penyisipan alur seperti yang ada di atas, terdapat juga dalam bab kedua, yakni dengan kemunculan Raja Lasem berserta pasukannya untuk mengambil Puteri Daha. Namun, penyisipan cerita lain dalam perjalanan alur dalam Wangbang Widèya: A Javanese Panji Romance mempunyai pengaruh yang kuat karena mendukung cerita akan selesai.

Eksposisi atau pendeskripsian cerita dalam bab ketiga berkisah tentang perjalanan Raden Makaradwaja yang berhasil menumpas Raja Lasem beserta pasukannya. Raja dan Ratu Daha menunggu kedatangan Raden Makaradwaja dengan cemas, dan mereka khawatir jika Raden Makaradwaja gugur. Perjalanan alur dalam Wangbang Widèya: A Javanese Panji Romance dalam bab ketiga bergerak maju karena tidak disisipi dengan cerita lain, dan cerita Wangbang Widèya: A Javanese Panji Romance akan berakhir dalam bab ketiga.

Unsur ketidakstabilan cerita dalam Wangbang Widèya: A Javanese Panji Romance terdapat dalam eksposisi bab pertama. Elemen ketidakstabilan mengembangkan cerita Wangbang Widèya: A Javanese Panji Romance supaya perjalanan plot yang ada di dalamnya lebih bervariasi. Unsur ketidakstabilan mulai terjadi ketika Puteri Daha menghilang dan Raden Makaradwaja berusaha mencarinya. Jika diteruskan pada kelurusan plot dalam, Raden Makaradwaja seharusnya terus mencari Raden 
Warastrasari yang menghilang. Namun, Raden Makaradwaja terpikat dengan wanita lain, sehingga dia berbalik arah menuju istana. Dari sinilah unsur ketidakstabilan mulai terjadi, sehingga plot menjadi berkembang.

Elemen ketidakstabilan juga muncul ketika Raden Warastrasari berada di dalam hutan, dan ia bertemu dengan Raden Singhamatra. Dari sinilah pola konflik terbentuk ketika Raden Warastrasari menikah dengan Raden Singhamatra. Ketika mendengar kabar pernikahan Raden Warastrasari, Raden Makaradwaja datang ke Daha dengan mengganti nama menjadi Waybay Wideya Apañji Wireswara. Di sana dia mengalami pergolakan batin ketika melihat kecantikan Puteri Daha. Dia ingin memiliki, namun di sisi lain Raden Warastrasari sudah mempunyai suami. Raden Makaradwaja merasa jatuh cinta terhadap Puteri Daha. Dia memikat Puteri Daha dengan kemahirannya dalam memainkan wayang, menari, serta mengalahkan musuh.

Konflik semakin bertambah ketika Raja Lasem hendak menyerang Daha. Dari satu sisi, Raden Makaradwaja mengalami tekanan batin karena perasaan cinta yang dia miliki. Dia harus menjadikan Puteri Daha terkagum-kagum padanya. Namun di sisi lain, Raden Makaradwaja harus berhadapan dengan musuh nyata yang hendak merebut Raden Warastrasari. Konflik dalam bab dua antara Kerajaan Daha dengan Raja Lasem mulai surut ketika Raja Lasem berhasil dikalahkan oleh Raden Makaradwaja. Namun, sebagai kelanjutan dari konflik bab pertama akan berlanjut pada bab ketiga. Intensitas konflik semakin menanjak sampai puncak, ketika Raden Makaradwaja menggelar pertunjukan dan dia sendiri menjadi penari. Ketika itu konflik mencapai titik tertinggi, maka komplikasi akan terjadi. Komplikasi pertama terjadi ketika Raja Lasem berhasil dikalahkan Raden Makaradwaja.

Komplikasi kedua mulai terjadi pada saat Raden Makaradwaja menari. Para undangan termasuk Raden Singhamatra mabuk dengan minuman keras atau arak yang dicampur dengan soporifik oleh Carang Lengkara. Setelah Raden Singhamatra dan para pengawal dalam keadaan mabuk, segera Raden Makaradwaja masuk ke dalam taman. Puteri Daha sedang duduk sambil merenungi nasibnya ketika di dalam taman. Antara Raden Makaradwaja dan Raden Warastrasari terjadi dialog. Klimaks terjadi pada waktu Puteri Daha menerima ajakan Raden Makaradwaja pergi dari Daha. Antara klimaks pertama dengan klimaks kedua bertolak belakang, karena klimaks pertama bermula dari konflik nyata yakni keinginan Raja Lasem memiliki Puteri Daha (konflik alam). Sedangkan klimaks yang kedua bermula dari konflik kejiwaan, yakni keinginan Raden Makaradwaja untuk memiliki Raden Warastrasari dengan berbagai cara untuk bisa memikatnya. Klimaks utama cerita Wangbang Widèya: A Javanese Panji Romance adalah klimaks kedua, yakni Raden Makaradwaja berhasil mendapatkan Raden Warastrasari setelah meperjuangankan selama delapan bulan di Daha. Klimaks utama ini merupakan rentetan perjalanan plot dalam Wangbang Widèya: A Javanese Panji Romance mulai dari awal sampai 
akhir. Walupun ada klimaks lain, namun klimaks itu merupakan varian dari klimaks utama.

Setelah pencapaian titik tertinggi dari cerita Wangbang Widèya: A Javanese Panji Romance melalui klimaks, maka cerita mulai mengalami penurunan alur atau plot melalui tabir yang terbuka yakni Wangbang Wideya Apañji Wireswara. Tergambar dengan jelas pertunangan Raden Makaradwaja dengan Raden Warastrasari melalui dialog Raden Singhamatra dalam bab ketiga, sebelum penyelesaian dari Wangbang Widèya: A Javanese Panji Romance diketengahkan. Adegan yang semula memanas karena Raden Warastrasari menghilang, kemudian berubah menjadi cair dengan kebijakan yang diperlihatkan oleh Raden Singhamatra terhadap bekas istrinya.

Penurunan plot semakin tajam dengan restu yang diberikan oleh Ratu Daha terhadap puterinya dan kemarahannya terhadap Raden Makaradwaja mereda. Denoument atau akhir dari hasil cerita Wangbang Widèya dalam buku Wangbang Widèya: A Javanese Panji Romance adalah kedamaian yang melingkupi Kerajaan Daha dan Kuripan melalui perkawinan Raden Makaradwaja dan Raden Warastrasari. Juga melalui pemerolehan jodoh antara Raden Singhamatra dengan Putri Lasem, Raden Srenggara-Yuda berjodoh dengan Putri Tilakusuma, Mpu Siwasmreti menikah dengan putri dari Empu Dyaksa Daha. Rangga Wicitra menikah dengan Ken Bayan, Ken Sanggit menikah dengan Banak Sudira, Ajaran Wirapaksa menikah dengan Ken Pasiran, Pembantu Raden Makaradwaja lainnya, seperti Carang Lengkara dengan Raden Ken Kesawati’s Bayan, dan Bango Rancana dengan Ken Sanggit.

\subsection{Tokoh dan Penokohan Cerita Wangbang Widèya dalam buku Wangbang Widèya: A Javanese Panji Romance}

Tokoh merupakan pelaku sentral yang menggerakkan cerita mulai dari eksposisi sampai denoument. Tokoh dan penokohan dalam teater tradisional atau dalam sastra lama bersifat statis, dalam artian tokoh utama sebagai tokoh protagonis yang digambarkan oleh pencerita sebagai manusia yang hanya memiliki sifat yang baik. Sebaliknya, tokoh antagonis diceritakan oleh pencerita sebagai manusia yang hanya memiliki sifat jahat.

Berbeda dalam teater modern atau sastra modern, tokoh yang diceritakan pencerita bersifat dinamis. Kedinamisan seorang tokoh dalam suatu cerita karena dipengaruhi oleh sifat-sifat manusia dalam dunia nyata. Tokoh dalam teater dan sastra modern selain bersifat baik kadang juga diselipi dengan sifat jelek. Hal ini mengacu pada sifat manusia dalam dunia nyata yang tidak memiliki kesempurnaan perilaku.

Tokoh-tokoh cerita Wangbang Widèya: A Javanese Panji Romance dapat dibagi dalam empat kategori, yakni tokoh-tokoh yang ada dalam kerajaan Kuripan, tokohtokoh yang terdapat dalam kerajaan Daha, tokoh-tokoh yang terdiri dari Kerajaan 
Lasem, dan tokoh-tokoh yang terdapat di Kerajaan Kembang Kuning. Tokoh-tokoh yang terdapat dalam kerajaan Kuripan meliputi Raja Kuripan, Raden Makaradwaja, Raden Srenggana Yuda, Empu Siwasmreti, Rangga Wicitra, Ajaran Wirapaksa, Banak Sudira, Carang Lengkara, Analap Sih, Gagak Prahara, Sadaku, Tan Mundur, Amunah Kusuma dan Tan Kokih. Dari pihak Kerajaan Daha, para tokoh meliputi Raja dan Ratu Daha, para selir, Raja Jagaraga dan istri, Raja Putrasena, Raden Warastrasari atau Puteri Daha, Ken Sanggit, Ken Bayan, Duta Liring, Ken Pasiran, Ken Pangunengan, Ken Pisanan, Raja dan Ratu Daha, dan Ken Bayan. Pihak kerajaan Kembang Kuning meliputi Raja Kembang Kuning dan Raden Singhamatra. Sedangkan Kerajaan Lasem diwakili oleh tokoh Raja dan Ratu Lasem, Raja Mataram, Raja Kabalan, Raja Camara, Raja Pajang, Raja Manungkuli, Para Patih, para Tumenggung.

Adapun tokoh utama adalah Raden Makaradwaja, Raden Warastrasari, dan Raden Singhamatra. Ketiga tokoh terlibat mulai dari awal hingga akhir cerita. Hal ini karena konflik yang ada bermula dari Raden Warastrasari menikah dengan Raden Singhamatra, namun di sisi lain Raden Makaradhwaja juga terpikat dengan Raden Warastrasari. Raden Makaradwaja adalah tunangan dari Raden Warastrasari, dan sesuai dengan judul cerita Panji yakni Wangbang Widèya: A Javanese Panji Romance, cerita dimenangkan tokoh Raden Makaradwaja. Intensitas cerita Wangbang Widèya: A Javanese Panji Romance pada tokoh Raden Makaradwaja, lebih banyak daripada Raden Singhamatra. Hal ini bisa diketahui lewat sikap Raden Makaradawaja terhadap Raden Warastrasari, perasaaan hati yang senang atau tertekan terhadap puteri Daha. Sedangkan penceritaan Raden Singhamatra hanya bersifat datar, seakan-akan hanya menjadi pelengkap tokoh yang mendukung proses penyelesaian cerita. Namun dalam bab ketiga, sikap yang dimiliki oleh para ksatria akan berbeda dengan bab pertama, dan menimbulkan sesuatu yang mencengangkan bagi pembaca.

Kata makaradwaja merupakan nama lain dari dewa Kama (cinta) ${ }^{16}$. Raden Makaradwaja adalah Putera Raja Kuripan. Dia lelaki yang tampan, bijaksana, pemberani, suka menolong orang lain, dan pintar dalam membaca kitab suci. Namun, sebagai seorang ksatria yang memiliki sifat-sifat yang luhur, dalam satu sisi dia juga gemar akan wanita. Hal ini terbukti dengan adanya beberapa istri yang dia miliki. Sifat suka perempuan nampak mendominasi watak seorang pangeran yang bernama Raden Makaradwaja. Walaupun dia sudah mempunyai tunangan seorang Puteri Daha (berkaitan dengan bab ketiga), akan tetapi dia juga mempunyai beberapa orang istri. Jika dikaitkan dengan inti cerita, kisah Panji memang memiliki kemiripan. Kemiripan itu terletak pada kesenangan Panji terhadap perempuan. Satu hal yang paling

${ }^{16}$ Zoetmulder. Kamus Jawa Kuna-Indonesia Bagian I A-Z. (Jakarta: Gramedia Pustaka Utama, 1995), hlm. 643. 
penting adalah, tema cerita Panji beserta varian-variannya selalu berkaitan dengan wanita.

Tokoh Panji, di samping mempunyai sifat baik, juga mempunyai sifat yang tidak baik. Hal ini terbukti ketika dia marah karena mendengar puteri Daha menghilang dan menikah dengan Pangeran dari Kembang Kuning. Tokoh Raden Makaradwaja dalam Wangbang Widèya: A Javanese Panji Romance tidak hanya bersifat baik, namun dia juga mempunyai sifat pemarah. Hal ini terjadi ketika dia mendengar pernikahan Raden Warastrasari. Intensitas penceritaan Raden Makaradwaja begitu mendominasi. Hal ini berkaitan dengan judul Wangbang Wideya, yang merupakan nama samaran dari Raden Makaradwaja ketika berada di Daha. Selain itu, tokohtokoh lain juga selalu berhubungan dengan Raden Makaradwaja, seperti saudarasaudaranya maupun para pembantu. Tanpa terkecuali orang-orang Daha sendiri juga mengagumi wajah dan sifatnya yang baik. Begitu juga dengan pertunjukan yang digelar oleh Raden Makaradwaja selalu berkenan di hadapan raja Daha dan orang-orang yang melihat pertunjukannya.

Tokoh lain yang tak kalah penting adalah Raden Warastrasari. Raden Warastrasari adalah putri Daha yang menghilang ketika akan menikah dengan Raden Makaradwaja. Perilaku yang ditunjukkan oleh Raden Warastrasari terhadap suaminya nampak acuh tak acuh. Hal ini terkait dengan kesedihan hatinya selama dia menikah karena dia tidak mendapatkan kesenangan.

Raden Makaradwaja terpikat kecantikan Raden Warastrasari, walaupun dia juga mempunyai istri yang sangat cantik. Demikian juga dengan Raja Lasem, dikarenakan kecantikan Raden Warastrasari, dia menginstruksikan pasukan-pasukannya untuk menyerbu Daha dengan satu tujuan yakni merebut Dewi Warastrasari.

Raden Singhamatra memiliki sikap sabar ketika istrinya telah dibawa lari oleh Raden Makaradwaja. Dia merelakan istrinya dibawa Raden Makaradwaja daripada mengadakan pembalasan terhadap Raden Makaradwaja. Dia tahu bahwa putera mahkota Kuripan orang yang sangat kuat. Alasan lain yang dikemukakan oleh Raden Singhamatra adalah Raden Makaradwaja dan Raden Warastrasari telah dipertunangkan sejak dalam kandungan, sehingga dia menyesali pernikahan yang seharusnya tidak terjadi.

Selain tokoh-tokoh di atas, terdapat juga tokoh yang bernama Raja Lasem, berasal dari Kerajaan Lasem dan ingin memiliki Raden Warastrasari. Raja Lasem adalah seorang raja yang kaya raya dengan pasukannya yang begitu banyak. Raja Lasem mempunyai dua saudara, yakni raja Mataram dan raja Manungkuli. Ketiga-tiganya merupakan raja yang ganas dalam peperangan. Raja Lasem pada waktu muda sangat keranjingan dengan wanita, dia juga mempunyai beberapa selir dengan kerajaan 
lain seperti dari Camara, Pajang, dan Manungkuli. Dia mengikat kerajaan mereka lewat pernikahan.

Pada suatu hari, Raja Lasem menyiapkan tentaranya untuk berperang melawan Kerajaan Daha. Raja Lasem sangat bernafsu untuk memiliki putri Daha karena sejak muda dia sudah gemar dengan wanita. Hal ini terbukti dengan beberapa selir yang dia miliki, dan tidak akan puas jika Putri Daha tidak berhasil dia dapat.

Diceritakan bahwa Raja Lasem beserta pasukannya mempunyai perilaku yang sangat buruk. Mereka menghancurkan kota-kota dan desa-desa yang dilalui, menangkap para lelaki dan perempuan. Para wanita dan anak-anak mereka hukum, perempuan-perempuan cantik mereka pilih untuk dijadikan istri simpanan atau selir dan semua wanita mereka perkosa.

Raden Kesawati dari Singasari merupakan istri yang paling cantik di antara istriistri putra mahkota Kuripan, sebelum dia bertemu dengan Raden Warastrasari dari Daha. Raden Kesawati merupakan istri pertama dari Raden Makaradwaja. Dia berasal dari Singasari, terkenal dengan kecantikan dan budi luhurnya. Semula Raden Makaradwaja hendak mencari Raden Warastrasari, tunangannya yang telah menghilang. Namun, Raden Makaradwaja tidak bisa menghilangkan bayangan Raden Kesawati, sehingga dia berbalik arah, dan pulang menuju Kuripan.

Pemilihan tokoh-tokoh di atas sebagai tokoh utama dikategorikan karena keterlibatan tokoh mulai awal sampai akhir cerita. Tokoh Raden Makaradwaja merupakan tokoh sentral, berdasarkan nama samaran dia ketika di Daha. Tokoh Raden Makaradwaja memerlukan ruang yang begitu banyak penceritaannya karena berhubungan dengan sifat, bentuk tubuh, perasaaan hati, keahlian dia dalam berperang, dan kecakapan dia dalam memainkan wayang serta menari. Tokoh Raden Singhamarta merupakan tokoh sentral yang juga memerlukan tempat begitu banyak penceritaannya. Namun, terkait dengan sikap, perasaaan hati, serta kecakapan yang dia miliki tidak begitu ditonjolkan di dalam kidung.

Tokoh dari kerajaan Lasem, yakni raja Lasem merupakan tokoh yang juga mendominasi dalam bab dua. Berkaitan dengan tema cerita Wangbang Widèya: A Javanese Panji Romance yakni perebutan para lelaki terhadap Raden Warastrasari, hal ini juga dilakukan oleh raja Lasem. Raja Lasem mempunyai tabiat yang jelek (suka mengumpulkan wanita) dan berusaha merebut Raden Warastrasari dengan cara memerangi kerajaan Daha. Pada waktu akan menyerbu kerajaan Daha, Raja Lasem beserta pasukannya juga berbuat kelaliman dengan menyerang Daha dan menghancurkan desa-desa, membunuh orang, menangkap para wanita dan memperkosanya, serta membantai ternak.

Tokoh sentral lain dari golongan wanita adalah Raden Warastrasari dari Daha. Tokoh ini memakan banyak tempat dalam cerita Wangbang Widèya: A Javanese 
Panji Romance karena terkait dengan perilaku, sikap, dan perasaan hati yang dia miliki terhadap Raden Makaradhwaja dan Raden Singhamatra. Raden Warastrasari merupakan tunangan putra mahkota Kuripan. Mereka telah ditunangkan orang tuanya sejak dalam kandungan. Hal ini berkaitan dengan pengembaraan dan penyamaran Raden Makaradwaja selama delapan bulan di Daha untuk merebut Raden Warastrasari yang telah dimiliki oleh orang lain.

Tokoh lain yang bernama Raden Kesawati juga dimasukkan tokoh sentral, walaupun ruang penceritaan tidak begitu banyak disebutkan. Namun, keterlibatannya dengan tokoh utama, yakni Raden Makaradwaja sebagai istri pertama, juga perlu diperhitungkan. Dengan kehadiran Putri Singasari, putra mahkota Kuripan berputar haluan (pulang) dan tidak mencari tunangannya.

Tokoh-tokoh lain merupakan tokoh pembantu yang ikut membantu tokoh-tokoh utama dalam menyelesaikan cerita Wangbang Widèya: A Javanese Panji Romance. Terkadang tokoh-tokoh pembantu itu berfungsi bukan sebagai tokoh yang membantu tokoh utama, namun sebagai pelengkap tokoh dalam ceritanya. Selain itu, tokoh-tokoh yang membantu Raden Makaradwaja adalah Raden Srenggara Yuda (adik), Empu Siwasmreti, Rangga Wicitra (kakak), Ajaran Wirapaksa, Banak Sudira, Carang Lengkara, Amunah Sari, Anurida Raga, Tan Kokih, dan Tan Mundur. Para tokoh ini adalah saudara, penasehat, dan pembantu-pembantu Raden Makaradwaja selama penyamarannya di kerajaan Daha.

Selain tokoh-tokoh pembantu yang turut membantu tokoh utama ada juga tokoh yang tidak begitu banyak mempunyai peranan dan bersifat datar dalam cerita Wangbang Widèya: A Javanese Panji Romance. Tokoh itu adalah Raja dan Ratu Daha, Empu Brahmaraja yang berfungsi sebagai pemberi restu terhadap Raden Makaradwaja dan Raden Warastrasari. Raja Jagaraga merupakan kerabat dari Raja Kuripan. Raja Gegelang adalah teman dari Raja Kuripan, sekaligus mertua dari Raden Srenggana Yuda. Putri Tila Kusuma adalah istri dari Raden Srenggana Yuda, Putri Mataram, Putri Empu Dyaksa Daha, Ken Pasiran, dan Ken Pagunengan. Tokohtokoh tersebut merupakan tokoh-tokoh tambahan yang berperan tidak begitu penting dalam cerita Wangbang Widèya: A Javanese Panji Romance.

Pada pihak Kerajaan Daha, tokoh-tokoh yang menjadi penyerta tokoh utama adalah Ken Bayan dan ken Sanggit. Mereka merupakan padanan punakawan limbuk dan Canggik dalam wayang kulit. Mereka yang mengasuh dan menyertai Raden Warastrasari dalam keseharian. Duta Liring merupakan orang kerdil yang merawat taman tempat Raden Warastrasari biasa bermain. Peranan Duta Liring tidak begitu dominan dalam membantu Raden Warastrasari. Dia hanya sebagai pengantar surat dari Raden Makaradwaja untuk Raden Warastrasari. Tokoh pembantu Ken Bayan dan Ken Sanggit begitu berperan besar dalam kehidupan Raden Warastrasari, karena mereka menjadi emban biyung di waktu suka dan duka. 
Tokoh-tokoh lain yang tidak begitu berperanan penting dari kerajaan Daha adalah raja, ratu, patih, istri, dan demang. Raja dan Ratu Daha merupakan orang tua dari Raden Warastrasari, yang beberapa kali terlibat dengan beberapa tokoh utama, namun kehadirannya hanya sebagai pemberi restu terhadap beberapa tokoh utama. Demikian juga dengan patih, istri dan demang yang peranannya tidak begitu penting dan bersifat datar dalam cerita Wangbang Widèya. Mereka hanya diceritakan satu kali oleh pengarang ketika Raden Warastrasari telah diketemukan oleh Raden Singhamatra.

Tokoh pembantu dari Kerajaan Kembang Kuning adalah Raja Kembang Kuning. Raja Kembang Kuning hanya memberikan ide dan restu terhadap Raden Singhamatra ketika ia telah menemukan Raden Warastrasari di hutan.

Tokoh-tokoh pembantu kerajaaan Lasem adalah Raja Mataram, Raja Camara, Raja Kabalan, Raja Pajang, dan Manungkuli, serta tumenggung. Mereka merupakan tokoh datar yang hanya membantu raja Lasem untuk mewujudkan keinginannya.

Dengan demikian, para tokoh-tokoh yang terdapat dalam cerita Wangbang Wideya di buku Wangbang Widèya: A Javanese Panji Romance terbagi dalam dua kategori yakni tokoh utama dan tokoh pembantu (bawahan).

\subsection{Latar Cerita Wangbang Widèya dalam Buku Wangbang Widèya: A Javanese Panji romance}

Terkait dengan cerita Wangbang Widèya: A Javanese Panji Romance, latar yang ada di dalamnya dapat dipilah-pilah berdasarkan kriteria di atas. Latar tempat dalam cerita Wangbang Widèya: A Javanese Panji Romance mengacu pada tempat terjadinya peristiwa yang melibatkan para tokoh, seperti di taman, balairung istana, hutan dan sebagainya. berikut ini deskripsi tentang latar tempat di dalam cerita.

Deskripsi latar tempat terkait dengan perjalanan Raden Makaradwaja ke desa-desa, padang, pantai-pantai, perbukitan, benteng pertahanan, dan pertapaan ketika mencari Raden Warastrasari. Tempat tinggal sementara Raden Warastrasari di Kembang Kuning adalah berada di taman, sebelum ia dikembalikan ke Daha. Latar tempat ketika Raja Daha akan bertemu dengan anaknya adalah di pintu gerbang kerajaan Daha. Panji Wireswara ketika hendak pergi ke Daha, dia singgah di Candi Bang. Candi Bang merupakan salah satu aspek latar tempat.

Latar tempat bagi Raden Warastrasari ketika dia merasa sedih adalah taman. Pada waktu Panji Wireswara mengalami pergolakan batin, tempat yang dia tuju adalah Taman Bagenda. Raja Lasem ketika bertemu dengan para menteri beserta keluarganya bertempat di luar istana. Dengan demikian, latar tempat dalam cerita Wangbang 
Widèya: A Javanese Panji Romance berada di sekitar istana, luar istana, desa, hutan, taman-taman istana, serta medan peperangan.

Latar waktu dalam cerita Wangbang Widèya: A Javanese Panji Romance mengacu pada waktu pagi, siang, sore dan malam. Latar sosial jika dikaitkan dengan status sosial para tokoh dapat dideskripsikan sebagai berikut: golongan rendah (pembantu) terdiri dari Ken Bayan, Ken Sanggit, Ken Pasiran, Ken Pisanan, Ken Pangunengan, Duta Liring, Carang Lengkara, Banak Sudira, Ajaran Wirapaksa, Analap Sih, Tan Munah, Tan Kokih, Amunah Kusuma, Sadaka; dan golongan tinggi (bangasawan) terdiri dari Raden Makaradwaja, Raden Singhamatra, Raden Warastrasari, Raden Kesawati, Puteri Mataram, Puteri Lasem, Raja Kembang Kuning, Raja dan Ratu Kuripan, Raja dan Ratu Daha, Raja dan Ratu Lasem, Raden Srenggana yuda, Empu Siwasmetri, Patih, Tumenggung, Raja Jagaraga, Raja Putrasena, Raja Pajang, Raja Manungkuli, dan Raja Camara.

\section{KESIMPULAN}

Cerita Panji merupakan salah satu cerita klasik yang tak akan pernah tuntas dalam berbagai kajian yang ada di dalamnya. Salah satu varian cerita Panji adalah Wangbang Widèya: A Javanese Panji Romance. Wangbang Widèya yang didekati dari aspek sastra yakni kajian intrinsik dalam naskahnya. Kajian intrinsik ini meliputi aspek tema, alur cerita, tokoh dan penokohan, serta latar cerita. Hasil akhir didapatkan bahwa anilisis intrinsik pada naskah klasik ini mempunyai pola yang sama dengan naskah modern. [] 


\section{DAFTAR PUSTAKA}

Manuba, Ida Bagus, Adi Setiyowati, dan Pudji Karyanto. Keberadaan dan Bentuk Transformasi Cerita Panji. Litera, I Volume 12, 2013

O. Robson. 1971. Wangbang Wideya: A Javanese Panji Romance. The Hague: Martinus Nijhoff.

R.Ng. Poerbatjaraka. 1968. Cerita Panji dalam Perbandingan. Jakarta: Gunung Agung

Soemanto, Bakdi. 2001. Jagat Teater. Yogyakarta: Media Pressindo.

Sudjiman, Panuti. 1998. Kamus Istilah Sastra. Jakarta: UI Press.

Sugiyono. 2016. Metode Penelitian Kuantitatif, Kualitatif dan R\&D. Bandung: Alfabeta.

Suminto, A.Sayuti. 2000. Berkenalan dengan Prosa Fiksi. Yogyakarta: Gama Media

Zaidah, Abdul Razak, dkk. 1994. Kamus Istilah Sastra. Jakarta: Balai Pustaka

Zoetmulder. 1995. Kamus Kuna-Indonesia bagian A-Z. Jakarta: Gramedia Pustaka. 